4. Gremmes S. Patologiya sustavov u sobak // Tezisy dokladov konferentsiy i seminarov XXI Mezhdunarodnoy spetsializi-rovannoy vystavki tovarov i uslug dlya domashnikh zhivotnykh "Zoosfera»11-13 oktyabrya 2012. Sankt-Peterburg, 2012. - S. 10-12.

5. Deniz Elliott, Erik Serve, Vinsent Biurzh. Diyetoterapiya pri osteoartrite u sobak // Veterinary Focus, 2008. - № 2 (17.3). - S. 43-50.

6. Exklusiv im Zoofachhandel. Dr.Clauder's Mobil \& Fit. Hamminkeln, 2016. - 12 s.

7. Khondroprotektory $v$ lechenii i profilaktike zabolevaniy oporno-dvigatel'nogo apparata u sobak // Journal of Small Animal Practice, 2011. - T. 2. - № 3. - S. 46.

8. Matveyev A. Primeneniye veterinarnykh diyet Royal Canin Mobility pri sustavnykh patologiyakh u sobak // Veterinariya se-godnya, 2009. - № 6. - S. 3-5.

9. Effektivnaya farmakoterapiya pri zabolevaniyakh oporno-dvigatel'nogo apparata // Journal of Small Animal Practice, 2010. - T. 1. - № 1. - S. 34-35.

10. Makarynska, A.V. Bílkovo-vítamínno-míneral'na dobavka dlya domashnikh tvarin// Zbírnik tez dopovídey 76 naukovö̈ konferentsiï vikladachiv akademiï 18 - 22 kvitnya 2016 r. Odesa: MON Ukraïni, ONAKHT, 2016. - S. 1315.

11. Makarynska, A.V. «Mobikan»- bílkovo-vitamínna dobavka dlya domashníkh tvarin. Makarynska A.V.// Zernoví produkti i kombikormi, 2017. - t. 17. - № 3 (67). - S. 38-44.

12. Makarynska, A.V. Tekhnologíya virobnitstva bilkovo-vítamínnoï dobavki dlya domashníkh tvarin "Mobíkan»// Zbirnik tez dopovidey 77 naukovoï konferentsiï vikladachív akademiï 18 - 21 kvitnya 2017 r. Odesa: MON Ukraïni, ONAKHT, 2017. - S. 21-23.

13. Kompozitsíya ingrediêntiv dlya virobnitstva billkovo-vitamínno-míneral'noï dobavki dlya sobak. Egorov B.V., Makarynska A.V., Dubovenko Í.E. № zayavki a201706574 ot 26.06.17.

14. Ctal'naya I.D., Garishvili T.G. Metod opredeleniya malonovogo dial'degida s pomoshch'yu kisloty/ $V$ kn. «Sovremennyye metody v biokhimii». - M.: Meditsina, 1977. - S. 66-68.

15. Levitskiy A.P., Stefanov A.V. Metody opredeleniya aktivnosti elastazy i yeye ingibitorov: metodicheskiye rekomendatsii/K.: GFTS, 2002. -15 s.

16. S., Frankel $S$. A colometric metod for the determination of serum glutomic oxalacetic and glutomic pyruvic transaminases/ Amer. J. Clin. Pathol. - 1957. - v. 28, № 1. - P. 56-63.

Надійшла 15.03.2018. До друку 26.03.2018

Адреса для переписки: вул. Канатна, 112, м. Одеса, 65039

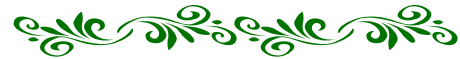

УДК 636.085.55: [664.12:661.155.5-027.33]

О.Є. ВОСЦЬКА, канд. техн. наук, доцент, І.С. ЧЕРНЕГА, канд. техн. наук, ст. викЛ.,

О.Г. ЦЮНДИК, канд. техн. наук, ас., М.О. МОГИЛЯНСБКИЙ, аспірант, І.В. ТЕПЛИХ, магістр

Одеська національна академія харчових технологій, м. Одеса

\title{
ПЕРСПЕКТИВИ ВИКОРИСТАННЯ ПОБІЧНИХ ПРОДУКТТВ ЦУКРОВОГО ВИРОБНИЦТВА
}

\section{Анотація}

В умовах постійних економічних спадів, нестабільного розвитку економічних проиесів та загальнополітичної нестабільності актуальним завданням для країни є забезпечення населення необхідними продуктами харчування та продовольством у иілому. Важливе значення у даному прочесі належить забезпеченню крайни одним з важливих продуктів харчування-иукром.

При виробнищтві иукру виникає иілий ряд побічних продуктів, які дуже швидко псуються і вимагають негайної утилізації. Побічні продукти при виробництві иукру є перспективною сировиною для годівлі тварин. Їх можна використовувати як у свіжому вигляді, так і після сушки, в гранульованому вигляді тощо. Проте, дані способи їх переробки не знайшли широкого застосування у комбікормовій галузі, оскільки супроводжуються втратами поживних речовин та високою вартістю.

Тому найбільш актуальним питанням иукрової промисловості на сьогоднішній день є визначення шляхів повного $і$ раціонального використання побічних продуктів, які утворюються в процесі виробництва иукру, розробка мало- $і$ безвідходних технологій, а також заходів по виключенню шкідливого впливу на навколишне середовище.

У статті розглядаються перспективні напрямки раціонального використання побічної продукції, що утворюється при виробництві иукру, а саме - бурякового жому. Наведена класифікація вторинних матеріальних ресурсів иукрового виробництва, дослідження хімічного складу та можливі способи переробки бурякового жому. Однак наведені способи не дозволяють повною мірою вирішити проблему переробки бурякового жому. Незважаючи на ряд переваг, проблема утилізаиії бурякового жому залишається актуальною для нашої краӥни.

Можливим способом використання бурякового жсму є його переробка у кормові добавки, що дасть змогу не тільки розширити асортимент сировини для виробництва комбікормової продукції та зменшити витрати на виробництво готової продукиії, а й вирішити проблему утилізації побічних продуктів иукрового виробництва та зменшити їх негативний вплив на навколишнс середовище.

Ключові слова: відходи, буряковий жом, утилізачія, переробка, комбікорм. 
Вступ

Цукрова промисловість $є$ однією із найважливіших галузей агропромислового комплексу України. За кількістю підприємств, виробничою потужністю, забезпеченням кваліфікованими працівниками вона займає одне із чільних місць в харчовій промисловості. У багатьох регіонах країни кліматичні умови сприятливі для вирощування буряків, що дає можливість інтенсивного розвитку виробництва цукру на основі власної сировини [1].

Інтенсивний розвиток промисловості та сільського господарства спричинив загострення численних екологічних проблем. Відомо, що цукрове виробництво - це складне матеріало- та енергоємне виробництво, у якому обсяги сировини та допоміжних речовин у декілька разів перевищують вихід готової продукції [2].

При виробництві цукру, крім основної продукції, утворюється значна кількість відходів, які на даний час недостатньо ефективно використовуються, а часом приносять значної шкоди навколишньому середовищу [2].

\section{Матеріали та методика досліджень}

Тому мета даної роботи полягала у проведенні аналізу і дослідженні способів переробки бурякового жому та вивченні можливості використання бурякового жому для отримання кормової добавки, як сировини для комбікормової продукції [2].

\section{Результати досліджень.}

При виробництві цукру вихід побічних продуктів становить, \% від маси буряків: бадилля $50 \ldots 70$, жому свіжого - 70...90, осаду фільтраційного $-8 \ldots 12$ і меляси $-4 \ldots 6$ [3-6].

Отже, цукрове виробництво є великим джерелом вторинних сировинних ресурсів і відходів [2]. На рис. 1 представлена класифікація вторинних матеріальних ресурсів цукрового виробництва [3-8]. В останні роки у цукровій промисловості намітилася тенденція зростання виробництва цукру 3 цукрових буряків і збільшення періоду переробки буряка на цукрових заводах [9].

За загальною масою найбільша частка твердих відходів цукрового виробництва припадає на жом. Більша частина жому в даний час не використовуються і перед початком нового виробничого сезону повинна вивозитися у відвали або на поля. Це призводить до забруднення навколишнього середовища та погіршує родючість землі [10].

Враховуючи обсяги переробки цукрових буряків, також те, що вихід сирого бурякового жому на цукрових заводах становить $80 \ldots 83$ \% до маси перероблених буряків, можна вирахувати обсяг виробленого бурякового жому цукровими заводами (рис. 2).

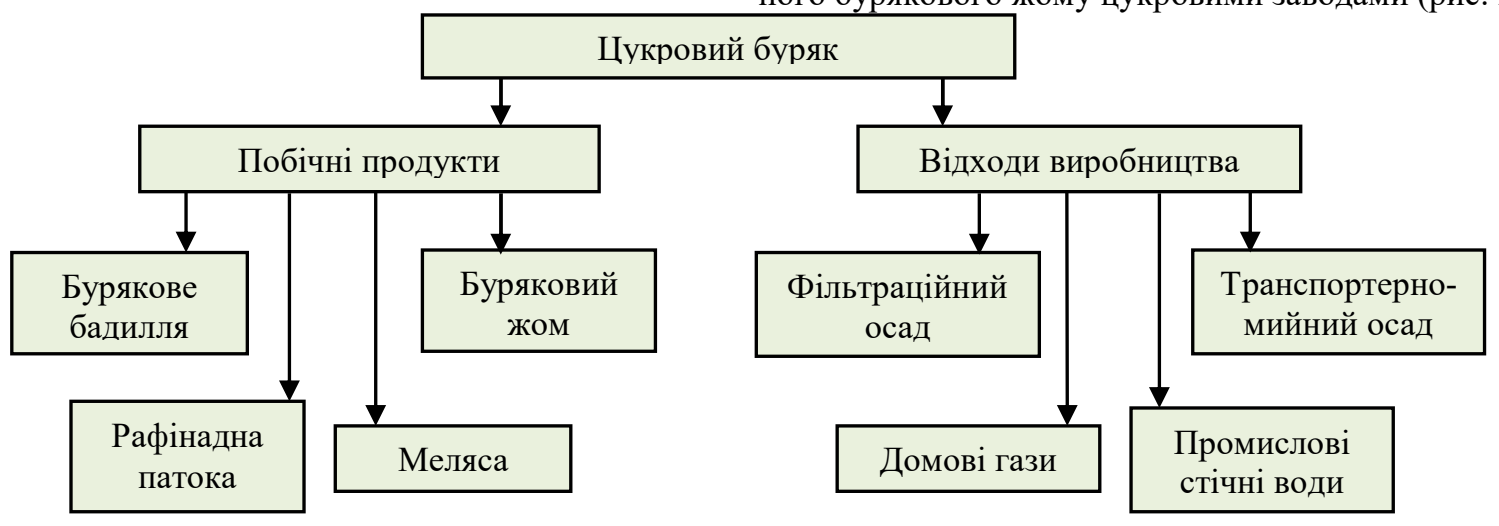

\section{Млн т}

Рис. 1 - Класифікація вторинних матеріальних ресурсів цукрового виробництва.

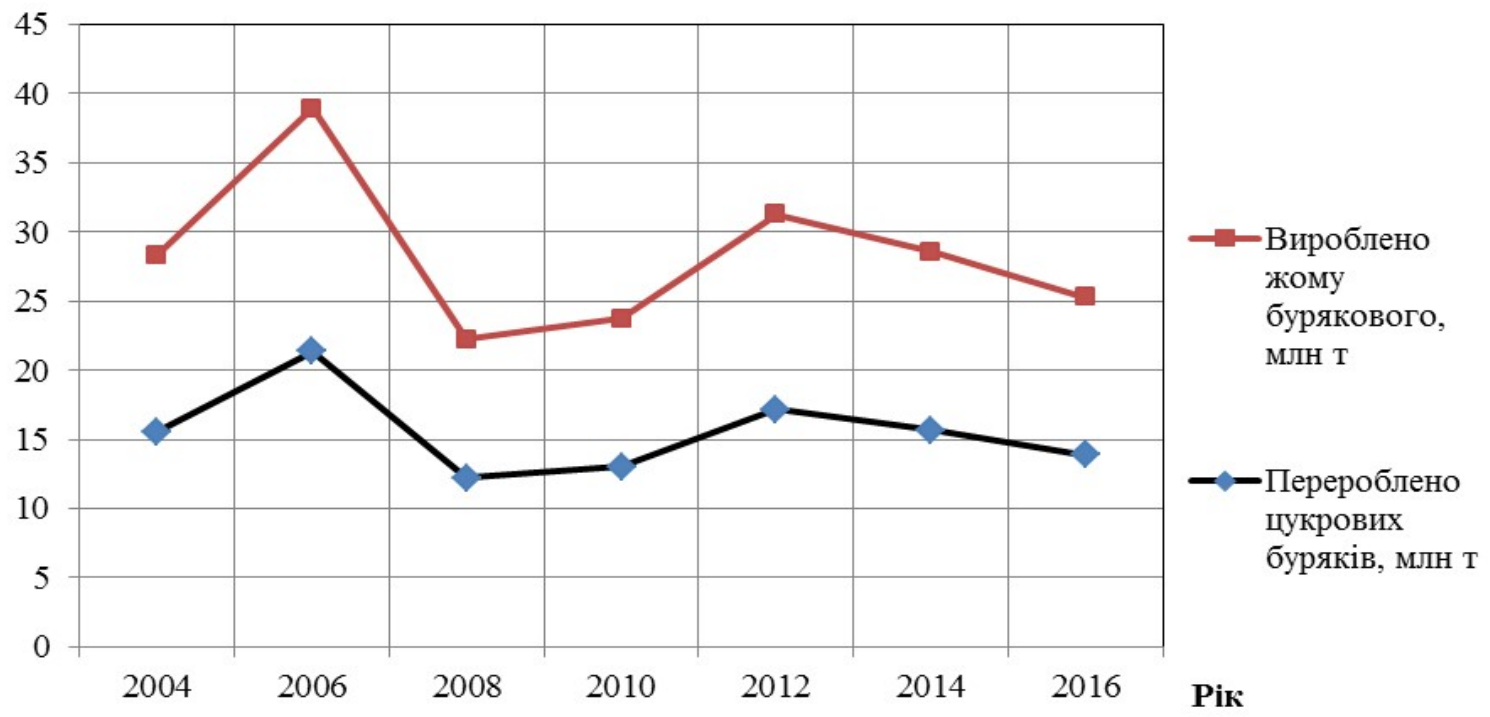

Рис. 2 - Динаміка виробництва бурякового жсому в Украӥні, млн. m [1]. 


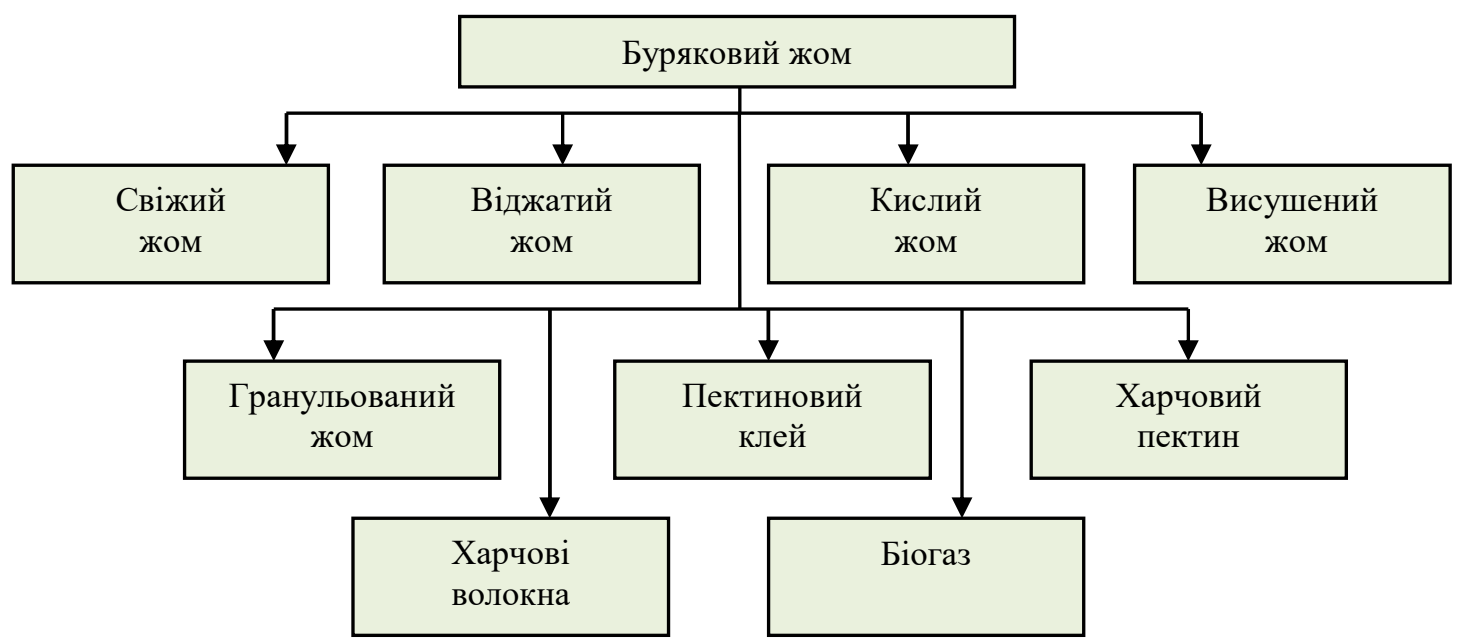

Рис. 3 - Класифікація продуктів переробки бурякового жому [3-8].

Аналіз динаміки виробництва бурякового жому показав, що протягом аналізованого періоду обсяг виробництва жому досить значний. Оскільки цей обсяг прямо залежить від кількості перероблених цукрових буряків, то його виробництво збільшується пропорційно збільшенню промислової переробки цукрового буряка [11].

Враховуючи великі обсяги переробки цукрових буряків та виробництва бурякового жому, можнавідзначити, що переробка, зберігання та утилізація бурякового жому являє собою серйозну проблему. Інтенсивно мінливі економічні умови господарювання у регіонах обробки цукрових буряків і розташування заводів 3 їх переробки надають особливий вплив на вирішення цієї проблеми.

На даний час можна виділити такі основні напрямки використання та утилізації бурякового жому: харчовий пектин, корм для тварин, силосування, сушка та гранулювання жому, біогаз, пектиновий клей, харчові волокна, паливо для ТЕЦ цукрового заводу тощо (рис. 3).

Основними напрямками утилізації жому на даний час $\epsilon$ використання його у годівлі тварин у свіжому, силосованому, висушеному та гранульованому вигляді [2].

Стружка цукрового буряка після того, як 3 неї був витягнутий цукор, залишає виробництво у рідкому стані, з вмістом води близько $90 \%$ і при те- мпературі близько $70^{\circ} \mathrm{C}$. За допомогою віджиму частину води видаляють. Так отримують сирий жом 3 вмістом сухої речовини від 20 до 30 \% і при температурі близько $50{ }^{\circ} \mathrm{C}[11]$.

Одним 3 основних напрямків застосування свіжого бурякового жому є використання як корм у тваринництві. Жом містить целюлозу, пектинові речовини, цукор, азотисті речовини, невелику кількість білку, а також вітаміни та мікроелементи (табл. 1).

Буряковий жом $\epsilon$ цінним кормом для сільськогосподарських тварин. У свіжому вигляді жом згодовують нетривалий час із-за прискорення інтенсивності процесу його окислення, як наслідок, втрати поживних речовин. Свіжий буряковий жом повинен бути згодований протягом 1...3 днів, щоб запобігти його псуванню.

Жом - дуже цінний корм для дійних корів, оскільки він поставляє у рубець енергію, але при цьому не містить крохмалю [11]. Він містить безазотистих легко засвоюваних речовин в 1,5 рази більше, ніж сіно і майже стільки ж, скільки овес.

Однією з негативних якостей жому є те, що він містить велику кількість води. 3 цієї причини в ньому активно розвиваються мікроорганізми і він швидко псується. Надлишковий вміст води у жомі ускладнює і здорожчує його транспортування, а також сушку.

Таблиця 1 - Хімічний склад жому різних видів (\% до маси відповідного жому) [12].

\begin{tabular}{|c|c|c|c|c|}
\hline \multirow{2}{*}{ Показники } & \multicolumn{4}{|c|}{ Жом буряковий } \\
\hline & свіжий & віджатий & кислий & висушений \\
\hline Суха речовина & $6,0-9,0$ & $14-20$ & $11-15$ & $86-93$ \\
\hline Вода & $91-94$ & $80-86$ & $85-89$ & $7-14$ \\
\hline Сирий протеїн & $1,2-1,5$ & $1,7-1,9$ & $1,3-2,6$ & $7-9$ \\
\hline Сира клітковина & $3,5-4,5$ & $5,0-7,0$ & $2,8-4,2$ & $19-23$ \\
\hline Безазотисті екстрактивні речовини & $4,3-6,5$ & $8,5-10,0$ & $2,7-5,8$ & $55-65$ \\
\hline Зола & $0,6-1,0$ & $1,1-1,4$ & $0,7-1,8$ & $2,4-4,3$ \\
\hline Жир & $0,4-0,7$ & $0,6-0,9$ & $0,7-1,0$ & $0,3-0,5$ \\
\hline Кількість корм. од. в 100 кг жому & $6-9$ & $15-20$ & $9-11$ & $90-95$ \\
\hline
\end{tabular}


Великий вміст води у жомі і швидке його заквашування викликають у тварин при невмілому згодовуванні різні шлункові захворювання: проноси, аж до кривавих, здуття шлунка - тимпанію, мокреці захворювання ніг, призводить в окремих випадках до паралічу ніг, гангренозному запаленню.

У жомі міститься незначна кількість протеїну і мінеральних речовин, особливо фосфору. Нестача фосфору при частому годуванні жомом викликає, особливо у молодняка, серйозні розлади в організмі і навіть захворювання: слабкість ніг, появу суглобових пухлин, ламкість кісток, сліпоту, втрату апетиту. У зв'язку з цим при жомовій відгодівлі балансування раціону за всіма елементами живлення має виключно важливе значення [12].

У свіжому вигляді використовується тільки частина жому. Значну частину сирого жому зберігають у жомових ямах. Дно і стінки ями бетонують i оснащують дренажем для відведення 3 жому так званої жомової води. Під впливом мікроорганізмів жом в ямах закисає і перетворюється у кислий.

До того ж, сьогодні, коли ціни на енергоносії зросли, сушінням жому багато заводів перестали займатися і цей цінний корм часто реалізується у кислому вигляді [13].

При зберіганні відбуваються не тільки процеси бродіння, а й інші процеси, у результаті яких нерозчинні речовини жому перетворюються у розчинні. Разом 3 жомовою водою розчинені речовини $\mathrm{i}$ кислоти виводяться через дренаж.

Таким чином, при зберіганні втрачається значна частина сухих речовин жому. За 5 місяців зберігання жом може втратити до 40 \% сухих речовин. Даний спосіб зберігання, який використовують на заводах, слід визнати абсолютно незадовільним.

Свіжий жом економічно невигідно транспортувати на значні відстані, тому свіжий жом використовують у відгодівельних пунктах поблизу заводів і найближчих господарствах [3-8].

Для кращого консервування жому його необхідно силосувати. Під час транспортування жом, особливо у великих кількостях, охолоджується незначно, тому дуже важливо силосувати його прямо 3 транспорту, без проміжного зберігання. Це дозволяє уникнути втрат поживності, забруднень, а також стимулює процес «гарячого бродіння».

Але все ж таки, перед силосування жом необхідно пресувати до вмісту сухої речовини $10 \ldots 12 \%$ і додавати до нього грубі корми - полову, солом'яну січку та інше, щоб масова частка вологи суміші становила $70 \%$. Масу добре утрамбовують, вкривають малоцінними грубими кормами, тирсою, потім м'якою жирною глиною (шаром $12 \ldots 15 \mathrm{~cm}$ ) i зверху утеплюють.

Температура жому повинна бути $25 \ldots 30^{\circ} \mathrm{C}$ i не повинно бути доступу повітря. У таких умовах йде молочно-кисле бродіння. Такий жом має більш високу якість і зберігається тривалий час.

Незважаючи на це, більше половини його кількості направляють у жомосховища. При цьому тривале зберігання жому не тільки призводить до втрати поживних речовин, а й погіршує екологічну ситуацію. За вивезення невикористаного жому і викидання його у навколишнє середовище заводам доводиться виплачувати великі штрафи. У зв'язку 3 цим, проблема тривалого зберігання або утилізації бурякового жому є вкрай актуальною. Одне з основних рішень цієї проблеми - сушіння бурякового жомy.

Тому, щоб уникнути втрат поживних речовин при зберіганні свіжого і кислого жому, для вирішення екологічної проблеми жом доцільно сушити [3-8].

Існує технологія енергозберігаючої безвідходної сушки та переробки бурякового жому. Сушіння жому здійснюють в два етапи: попередне зневоднення жому до вологості $40 \ldots .55 \%$, що зменшує час сушіння в каскадній сушарці до вологості $12 \ldots 14 \%$ [13].

Сухий жом містить близько 90 \% сухої речовини. За кількістю кормових одиниць сухий жом майже дорівнює вівсу, тобто в два рази корисніше сіна і в три рази - вівсяної соломи.

Переваги цього продукту перед попереднім легке транспортування та тривале зберігання. Сухий жом включають до складу комбікормів для корів і молодняка ВPX [11].

Для отримання однієї кормової одиниці у жомі при сушінні доводиться витрачати близько 1 кг умовного палива. Під час тривалої сушки при підвищеній температурі цукор, білки, вітаміни жому частково руйнуються. Підвищення продуктивності сушарок, здешевлення сушки досягається попереднім видаленням частини води з сирого жому.

Однак, слід мати на увазі, що в процесі віджимання жом втрачає до $10 \%$ розчинних поживних речовин. У вітжатому жомі менше цукру, а це негативно позначається на його заквашуванні при силосуванні, впливає на якість зберігання. [12].

Ще одним побічним продуктом цукрового виробництва є мелясований жом. На цукровому заводі жом змішують 3 мелясою, а потім піддають сушінню. Після сушіння масу гранулюють, зазвичай, через матрицю з отворами діаметром 12 мм.

Мелясований жом містить ще більше енергії, у порівнянні з сухим жомом. Залежно від кількості введеної меляси вміст цукру у кінцевому продукті становить $13 \ldots 28 \%$. Розщеплення у рубці такого корму проходить рівномірно, завдяки чому він добре засвоюється тваринами.

Мелясований жом добре підходить для годівлі ремонтного молодняку на випасі. Це один зі стандартних компонентів для виробництва комбікорму для дійних корів $[11,14]$.

Низька об'ємна маса висушеного жому у розсипному вигляді (близько $250 \mathrm{\kappa г} / \mathrm{m}^{3}$ ) не дозволяє раціонально використовувати площі складів і вантажопідйомність транспорту. У зв'язку 3 цим сушений жом доцільно гранулювати. При цьому об'ємна маса його збільшується в 2...3 рази, що значно скорочує втрати жому при вантажно-розвантажувальних роботах, полегшує механізацію роздачі корму на фермах. Крім того сушений жом бідний протеїном, фосфо- 
ром, мікроелементами і вітамінами. Тому жом збагачують різними речовинами.

Виробництво амідного гранульованого жому здійснюють наступним способом. Сушений жом накопичують у бункері, зважують і подають у дозатор. Відміряна порція сушеного жому надходить на гвинтовий конвеєр. Сюди ж надходить порція обесфтореного фосфату. Жом і фосфат проходять магнітний сепаратор для видалення металомагнітних домішок i потрапляють в змішувач.

Мелясу змішують з розчином карбаміду у заданому співвідношенні і суміш перекачують в змішувач. У змішувачі всі компоненти ретельно перемішують і подають у прес-гранулятор. Отримані гарячі гранули охолоджують в охолоджувальній колонці, в яку вентилятором нагнітають повітря. При цьому гранули підсушують і спеціальна сушарка не потрібна. Жомовий пил з повітря відокремлюють у циклоні. Охолоджені і підсушені гранули подають на ваги і потім у склад.

Таким чином, можна отримувати гранульований жом $з$ різними добавками: мелясою, карбамідом, згущеною бардою спиртового і дріжджового виробництва та ін. [3-8].

Гранульований жом використовують для підкормки великої рогатої худоби узимку, оскільки це дозволяє навіть в зимовий період підтримувати приріст живої маси худоби та високий удій корів. Гранульований жом використовують для молочної худоби у якості одного $з$ компонентів у кормових сумішах або для прямого згодовування на молочних фермах. За кормовими характеристиками, гранульований жом здатен замінити біля 50 \% вівса або ячменю, тому, його активно використовують у сільському господарстві.

Проте дані способи переробки бурякового жому також не знайшли широкого розповсюдження, оскільки призводять до втрат поживних речовин та значним витратам, оскільки сушіння є досить енерговитратним процесом.

Буряковий жом може бути успішно використаний для виробництва пектину, що є цінним природним біокоректором та желеутворюючим компонентом. У країнах Свросоюзу виробляють не тільки сухий пектин, а й такі продукти, як пектиновий екстракт і концентрат, пектиновмісний порошок і пасту, пектин медичного призначення [15].

Одним 3 найбільш перспективних і затребуваних напрямів використання бурякового жому $є$ виробництво харчових волокон. Харчове волокно являє собою залишки рослинних клітин, які здатні проти- стояти гідролізу, що здійснюється травними ферментами людини.

3 бурякового жому виробляють також пектиновий клей. Спосіб отримання клею оснований на переведенні у розчин нерозчинних у холодній воді пектинових речовин, що містяться у жомі. Вихід клею при цьому становить 2,5...3 \% до маси свіжого жому.

Буряковий жом (свіжий і висушений) являє собою серйозний потенціал для виробництва енергії. Вiн може бути використаний як сировина для біогазових установок [16].

Крім основної вигоди - отримання біогазу установки забезпечують поліпшення екологічної ситуації навколо цукрового заводу, тому що дозволяють зменшити санітарну зону навколо підприємства 3 500 до 150 м. Використання бурякового жому як сировини біогазових установок дозволяє отримувати $60 \ldots 70 \mathrm{~m}^{3}$ газу 31 т сировини. Біогаз - це газ, що складається з 50..70 \% метану і $50 \ldots 30$ \% вуглекислого газу, і за своїми характеристиками близький до природного газу. Використання біогазу як палива для теплоелектрогенератора забезпечує отримання 2 кВт/год електричної та 2 кВт/год теплової енергії 3 $1 \mathrm{~m}^{3}$ газу [16].

Також можливі наступні напрями його використання - як вторинного палива сушеного жому та безпосереднє спалювання віджатого жому [10].

\section{Висновки}

Використовуючи ефективно відходи, підприємства отримують максимальний прибуток, наближаючи технологію до безвідходної, тим самим вирішують екологічну проблему і дають можливість організувати нові виробництва і отримувати додаткову продукцію. Однак ці заходи не дозволяють повною мірою вирішити проблему переробки бурякового жому. Незважаючи на ряд переваг, які дає використання бурякового жому в кормовиробництві, його переробка не є економічно виправданою, так як сушка $є$ досить енерговитратним процесом. Тому ефективним шляхом вирішення проблеми використання побічних продуктів цукрового виробництва при виробництві комбікормів $\epsilon$ удосконалення технології переробки бурякового жому у кормові добавки.

Раціональна комплексна утилізація відходів цукрового виробництва дозволить не тільки істотно підвищити ефективність виробництва цукру, але й розширити асортимент комбікормової продукції, зменшити витрати на випуск готової продукції і вирішити проблему утилізації бурякового жому.

\section{ЛІТЕРАТУРА}

1. Панасенко Н.Л. Аналіз динаміки показників виробнищтва иукру в Україні та аналітичні прогнози його розвитку // Развитие производительных сил и региональная экономика. - №1/7(21). - 2015. - C. 23-28.

2. Бордун I.М. Новий спосіб утилізації бурякового жому / І.М. Бордун, В.В. Пташник, М.М. Садова, Р.Б. Чаповська // Цукор України. - №6-7 (126-127). - 2016. - С. 45-47.

3. Денщиков М.Т. Отходы пищевой промышленности и их использование. - М.: Пищепромиздат, 1963-615с.

4. Образование и пути использования вторичных материальных ресурсов сахарной промышленности СССР. - М.: АгроНИИТЭИПП. Серия

5. Сахарная промышленность. Выпуск 3. - 1988 г.

6. Сапронов А.Р. Технология сахарного производства. - М.: Колос, 1998. - 495с.

7. Силин П.М. Технология сахара. - М: Пищевая промыциленность.1967. - 625c.

8. Журналье «Сахар», $2000-2009$ г2. 
9. Зелепукин Ю.И. Совместная переработка свекль и сахара-сыриа / Ю.И. Зелепукин, В.М. Фурсов, С.Ю. Зелепукин // Caxap. - №3. - 2014. - C. 50-52.

10. Шутюк В.В. Дослідження варіантів виробництва твердого палива з відходів иукрового виробництва та умов його спалювання / В.В. Шутюк, К.О. Штангеєв, Т.П. Василенко, С.М. Самійленко // Цукор України. - 2014. - № 12 (108). - C. 20-24

11. Четверик О.В. Аналіз ринку основної та побічної продукиї бурякоиукрового виробництва: стан та перспективи розвитку / О.В. Четверик // Вісник Академії праџі і соціальних відносин Федераиї профспілок України. - 2014. - № 3-4. - C. $92-100$.

12. Колесников Н.В. Хранение и использование свекловичного жома / Н.В. Колесников // М.: Россельхозиздат, 1980 $155 \mathrm{c.}$

13. Булавин С.А. Безотходная энергосберегающая технология переработки свекловичного жома / С.А. Булавин, К.В. Казаков, А.С. Колесников // Сахар. - №3. - 2011. - С. 36-38.

14. Продукты переработки сахарной свеклы в кормлении КРС. - Режим достуny: https://soft-agro.com/korovy/produktypererabotki-saxarnoj-svekly-v-kormlenii-krs.html

15. Зелепукин Ю.И. Целесообразность переработки отходов свеклосахарного производства / Ю.И. Зелепукин, С.Ю. Зелепукин // Caxap. - №5. - 2016. - C. 37-40.

16. Сучасні напрямки використання та утилізачії бурякового жому. - Режим доступу: http://diamantsugar.com.ua/ua/articles/sychasn-napryamki-vikoristannya-ta-ytilzats-byryakovogo-zhomy

\title{
O. VOIETSKA, PhD. Sc., Ass. Prof., I. CHERnEGA, PhD. Sc., A. TSIUNDYK, PhD. Sc., M. MOHYLYANS'KY, postgraduate, I. TEPLYKH, master's degree Odessa National Academy of Food Technologies, Odessa \\ PERSPECTIVES OF USE OF SUCCESSFUL PRODUCTION SUBSIDIARIES
}

\begin{abstract}
In the conditions of constant economic downturns, unstable development of economic processes and general political instability, the urgent task for the country is to provide the population with the necessary food products and food in general. Important in this process is the provision of the country with one of the important food products -sugar.

In the production of sugar, there are a number of by-products that are very quickly spoiled and require immediate disposal. By-products in the production of sugar are an interesting raw material for feeding animals, they can be dried, pelletized, and the like. However, these methods of their processing have not been widely used in the feed industry because they are accompanied by nutrient losses and high costs.

Therefore, the most pressing issues of the sugar industry today are the determination of the ways of full and rational use of by-products that are produced during the production of sugar, the development of small and non-waste technologies, as well as measures to eliminate the harmful effects on the environment.

The article deals with the perspective directions of rational use of by-products produced during the production of sugar, namely beet pulp. The classification of secondary material resources of sugar production, a study of the chemical composition and possible methods of processing beet pulp was given. However, these methods do not allow to fully solve the problem of processing beet pulp. Despite a number of advantages, the problem of utilization of beet pulp remains relevant for our country.

A possible way of using beet pulp is its processing in feed additives, which will enable not only to expand the range of raw materials for the production of feed products and reduce the cost of production of finished products, but also to solve the problem of utilization of by-products of sugar production and to reduce their negative impact on the environment.
\end{abstract}

Key words: waste, beet pulp, utilization, processing, feed.

\section{REFERENCES}

1. Panasenko N.L. Analysis of dynamics of sugar production indicators in Ukraine and analytical forecasts of its development // Development of productive forces and regional economy. - №1/7 (21). - 2015. - P. 23-28.

2. Bordun I.M. New way of utilization of beet pulp /I.M. Bordun, V.V. Ptashnik, M.M. Sadova, R.B. Chapovska // Sugar Ukraine. - №6-7 (126-127). - 2016. - P. 45-47.

3. Denshchykov M.T. Food industry waste and their use. - Moscow: Pishepromizdat, 1963. - 615p.

4. Formation and ways of using the secondary material resources of the sugar industry of the USSR. - M .: AgniNITEIPP. Series

5. Sugar industry. Issue 3. - 1988 .

6. Sapronov A.R. Sugar production technology. - M.: Kolos, 1998. - 495 p.

7. Silin P.M. Sugar technology. - M: Food industry. 1967. - 625s.

8. Magazines "Sakhar", 2000 - 2009.

9. Zelupukin Y.I. Joint processing of beets and raw sugar / Y.I. Zelupukin, V.M. Fursov, S.Y. Zelupukin // Sugar. - №3. - 2014. P. 50-52.

10. Shutyuk V.V. Investigation of variants of production of solid fuel from waste products of sugar production and conditions of its combustion / V.V. Shutyuk, K.O. Shtangeev, T.P. Vasilenko, S.M. Samiilenko // Sugar Ukraine. - 2014. - №12 (108). - P. 20-24.

11. Chetverik O.V. Market analysis of the main and by-products of beet and sugar production: the state and prospects of development / O.V. Chetverik // Bulletin of the Academy of Labor and Social Relations of the Federation of Trade Unions of Ukraine. 2014. - №3-4. - P. 92-100.

12. Kolesnikov N.V. Storage and use of beet pulp / N.V. Kolesnikov // M.: Rosselkhozizdat, 1980. - 155 p., 
13. Bulavin S.A. Non-waste energy saving technology for processing beet pulp / S.A. Bulavin, K.V. Kazakov, A.S. Kolesnikov // Sugar. - №3. - 2011. - P. 36-38.

14. Sugar beet processing products in feeding cattle. - Access mode: https://soft-agro.com/korovy/produkty-pererabotki-saxarnojsvekly-v-kormlenii-krs.html

15. Zelupukin Y.I. The expediency of processing of beet sugar production waste / Y.I. Zelupukin, S.Y. Zelupukin // Sugar. - №5. 2016. - P. 37-40.

16. Modern directions of use and utilization of beet pulp. - Access mode: http://diamantsugar.com.ua/ru/articles/sychasnnapryamki-vikoristannya-ta-ytilzats-byryakovogo-zhomy

Надійила 27.01.2018. До друку 08.02.2018

Адреса для переписки:

вул. Канатна, 112, м. Одеса, 65039

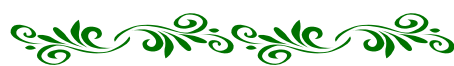

УДК [639.3.043:639.211]-021.4

LIUDMYLA FIHURSKA, PhD, Assistant Professor, Department of Feed and Biofuel Technologies Odessa National Academy of Food Technologies

\section{TENDENCIES AND PECULIARITIES OF SHRIMP FEED PRODUCTION}

\section{Abstrakt}

Aquaculture is food sector, which is growing rapidly in the last 25 years with annual growth rate 8,2\%. One of the most perspective branches of aquaculture is shrimp farming. The cost of feeds is up to $80 \%$ of the cost of shrimp breeding, so providing the industry with high-quality feeds is the important goal of the feed industry in all over the world. The theoretical research was devoted to the task of compound shrimp feed production. In order to satisfy shrimp requirements, shrimp feeding systems were shown. Existing shrimp breeding systems are shown as different from the type of reservoirs (static / running water, indoor or outdoor), feeding methods, and the species of grown shrimp. Features of the nutritional standards for freshwater and saltwater shrimps were analyzed. Nutrient requirements of shrimp have been changed through shrimp life-cycle. The shrimp life-cycle was shown.

World leaders-producers of compound mixed feeds for shrimps were shown. The analysis of pellet size and nutritional value of compound mixed feeds of crude protein content in prestart, starter, grower and finish periods of cultivation and in accordance with the system of cultivation and feeding shrimp (intensive, extensive, semi-intensive) is carried out. The requirements for the content of main minerals, vitamins and restrictions to the content of crude fiber are given. Traditional ingredients are described. Binders and preservatives, which are used for shrimp feeds, are shown and subscribed. In raw material the main problem is the need to ensure high protein content in the shrimp feed recipes. Because of many factors, fish meal quantity should be reduced in recipes. Because of its attractive amino acid content, availability and relatively affordable price, soybean meal and soy concentrates have received increasing attention as substitutes for marine animal meals.

The features of technological lines and processes of production of mixed feeds for shrimp are shown.

Ehe advantages and disadvantages of using the two most common processes of production of shrimp feeds (pelleting and extrusion), despite the relatively high cost extrusion, undoubtedly, is the main process of shrimp feed production.

At the same time, there are challenges, which need to be overcome by the industry for effective further development: to produce environmentally friendly feeds, to conduct further studies in order to clarify the required nutritional value of shrimp feed and add amino acids, feed enzymes, chemo-attractants, probiotics, and immunostimulants, to provide the necessary water stability of pellets, and to increase feed conversion rate, develop regional, national, or international guidelines and codes of practices for both feed manufacturing practices and feed management practices, reduce fish meal in shrimp feed recipes.

Despite the existence of problems, shrimp production is growing and the production of feed for their feeding has a great potential as an important source of animal protein in human nutrition.

Key words: compound feed for shrimp, feed manufacture technology for shrimp feed, requirements for shrimp feed.

Aquaculture has seen tremendous growth since 2011 , increasing market share by as much as $17 \%$ per year. The Food and Agriculture Organization of the United Nations (FAO) has released data indicating that trends in global consumption of farmed fish and shellfish exceeds that of beef on a weight basis [1]. Shrimp (or prawn) culture is widespread throughout the tropical world. It is in an industry set for a period of strongly growing demand, and is currently worth around US\$10 billion.

This article is intended to provide some detailed discussion, and information references where possible, on the perspectives and features of shrimp feed production.

Farming system and feeding strategies vary with shrimp size (larval, nursery, juvenile, adult), species and countries. Framing and feeding strategies used by farmers include [2]:

- extensive outdoor farming system with no additional nutrient input through fertilization or feeding (L. vannamei, P. monodon, P. chinensis, P. indicus.).

- extensive tidal/ running water outdoor farming system with fertilizer and / or complete / supplementary diet feeding (L.vannamei, P.monodon, P.chinensis, P.indicus)

- semi-intensive static / running water outdoor farming system with fertilizer and / or complete / supplementary diet feeding. (P.monodon, P.chinensis, L.vanname).

- intensive outdoor running / static water farming system with fertilizer and / or complete / supplementary diet feeding (P. monodon, L. vanname, F. dorarum, 